Nota científica

(Short communication)

\title{
USE OF BIOLOGICAL RESOURCES BY ELACHISTOCLEIS PEARSEI (RUTHVEN, 1914) (ANURA: MICROHYLIDAE) IN A LENTIC ECOSYSTEM FROM THE DEPARTMENT OF SUCRE, COLOMBIA
}

\author{
USO DE RECURSOS BIOLÓGICOS POR ELACHISTOCLEIS PEARSEI (RUTHVEN, 1914) \\ (ANURA: MICROHYLIDAE) EN UN ECOSISTEMA LÉNTICO DEL DEPARTAMENTO \\ DE SUCRE, COLOMBIA
}

\author{
Pedro ATENCIA GÁndARA, Óscar CONDE, \& Liliana SOlANo
}

\begin{abstract}
Grupo de Investigación en Biología Evolutiva, Departamento de Biología, Universidad Sucre. Carrera 28 No. 5 -267 Barrio Puerta Roja -Sincelejo - Colombia. <plag665@gmail.com>, <condeoscar93@gmail.com>, $<$ liliana.solano@unisucre.edu.co>

Recibido: 28/04/2016; aceptado: 31/10/2016

Editor responsable: Gustavo Aguirre León
\end{abstract}

\begin{abstract}
Atencia-Gándara, P., Conde, Ó., \& Solano, L. (2017) Use of biological resources by Elachistocleis pearsei (Ruthven, 1914) (Anura: Microhylidae) in a lentic ecosystem from the department of Sucre, Colombia. Acta Zoológica Mexicana (n.s.), 33(1), 130-132.
\end{abstract}

\begin{abstract}
The use of resources (diet, time of activity and microhabitat) by Elachistocleis pearsei in a locality of the department of Sucre is described. The non-invasive method used to obtain the digestive tract content showed high effectivity. Results show that this species is an active specialist forager that principally ingests ants, nevertheless diet composition is diverse; its activity is limited to the outskirts of the water source and increases in the season of higher precipitation.
\end{abstract}

In Colombia Elachistocleis pearsei occurs in lowlands, from 0 to $1015 \mathrm{~m}$ of altitude, along the Caribbean and the Magdalena river valley (Acosta-Galvis 2012), where this species inhabits ecosystems like savannas, which are highly perturbed habitats, and the Tropical dry forest, considered one of the most altered and threatened ecosystems due to the decrease of its original area (Miles et al. 2006; IAVH 2014). Elachistocleis pearsei exhibits a marked seasonality; it is active during periods of high precipitation in permanent and temporal lagoons and ponds, as well as floodplains and small streams (Acosta-Galvis 2012). The use of resources of one given species includes its microhabitat, diet, and time of activity; such aspects are important in the ecological structure of an assemblage of
Atencia-Gándara, P., Conde, Ó. y Solano, L. (2017) Uso de recursos biológicos por Elachistocleis pearsei (Ruthven, 1914) (Anura: Microhylidae) en un ecosistema léntico del departamento de Sucre, Colombia. Acta Zoológica Mexicana (n.s.), 33(1), 130-132.

RESUMEN. Se describe el uso de recursos: dieta, tiempo de actividad y microhábitat, por la especie Elachistocleis pearsei en una localidad del departamento de Sucre. El método no invasivo utilizado para extraer el contenido estomacal mostró alta efectividad. Los resultados indican que la especie es una forrajera activa y especialista que consume mayormente hormigas, aunque la composición de su dieta es más amplia; su actividad se limita a los alrededores del cuerpo de agua e incrementa en temporada de alta precipitación

anurans (Toft 1985; Muñoz-Guerrero et al. 2007; BlancoTorres 2009). Herein, we contribute to the knowledge of some important aspects of the natural history of $E$. pear$s e i$, in the department of Sucre, Colombia.

From May $27^{\text {th }}$ to June $10^{\text {th }}, 2015$ (first rainy period of the year) frog sampling was conducted from Monday to Friday, from 19:00 to 22:00 hours, in a "jagüey" (temporary pond) located at $209 \mathrm{~m}$ of altitude in position southeast in the University of Sucre $\left(9^{\circ} 18^{\prime} 50,861^{\prime \prime} \mathrm{N}\right.$ $\left.75^{\circ} 23^{\prime} 16,376^{\prime \prime} \mathrm{W}\right)$. The locality is considered Tropical dry forest, because it has warm weather, mean annual temperature of $27^{\circ} \mathrm{C}$, relative humidity of $77 \%$ and mean annual precipitation of $1090 \mathrm{~mm}$ (Aguilera 2005). The pond is surrounded by a herbaceous coverage, clay soil, 
a few big mature trees and zones of small shrubs; its soil has a leaf litter layer, humid organic matter near the pond and dry organic matter further apart. By direct catching, we collected 24 frogs (12 males and 12 females). For every collected individual, the following morphometric data were gathered: Snout-vent length (SVL) and head width (HW), using a manual caliper Discover. Moreover, in the field the time of capture, and the location of the individual with respect to the water source, according to three preestablished distances were recorded: $0-3 \mathrm{~m} ; 3-7 \mathrm{~m}$ and 7-12 m; finally, the type of substrate each individual was on (leaflitter, grassland, rubble, organic matter and clay soil) was categorized.

To avoid causing a demographic impact on the population, a non-invasive method to extract the stomach content, called stomach- flushing (Solé et al. 2005) was applied; at the end of the procedure, the frogs were released back in the collection sites. The items obtained from the stomach contents were identified to the level of order, following taxonomic keys. The frequency of occurrence of prey was estimated as the number of times we counted the prey appearing in the stomachs with contents $(n=21)$. Statistical analyses included the Index of dietary importance (IIA, from Spanish abbreviation) (Sampedro et al. 2011); trophic niche overlap between males and females was evaluated with the Jaccard simirality index and the minimum common percentages index (QR) (Odum 1984); to assess differences in time of activity between males and females a chi square test $\left(\chi^{2}\right)$ was applied to the frequency of encounter of every sex in three time intervals.

During rainy periods, Elachistocleis pearsei exhibits a peak of activity between 19:00 and 21:00 hours, followed by a general decrease in the number of individuals, males ceasing to call around the pond; there was not significant difference in the time of activity between males and females (Table 2). In absence of rain, there was a noticeable decrease in the activity of the frogs, making them difficult to sample; therefore, it was not possible to gather any data for the dry season of the year. Most individuals of the species $(91.7 \%)$ were found between 0 and 3 meters around the pond; frogs were rarely seen at distances beyond $3 \mathrm{~m}$, except after heavy rain, when some individuals standing on very humid clay soil or hiding under the vegetation, were observed in all the surroundings of the pond. The 12 males collected, had an average SVL of $33.55 \mathrm{~mm}$ (range $=30-39 \mathrm{~mm})$ and an average $\mathrm{HW}$ of $8.16 \mathrm{~mm}$ (range $=7$ - $9 \mathrm{~mm}$ ). The 12 females had an average SVL of $39 \mathrm{~mm}$ $($ range $=32.1-45.1 \mathrm{~m})$ and an average HW of $9.09 \mathrm{~mm}$ $($ range $=8-11.5 \mathrm{~mm})$. Twenty one $(87.5 \%)$ of the individ- uals regurgitated stomach contents. A total of 293 preys were found, belonging to six taxonomic orders: Hymenoptera, Coleoptera, Orthoptera, Diptera, Acari and Isoptera. The most abundant order was Hymenoptera $(95.56 \%$, IIA $=91.01 \%$ ) (Table 1), which was the main type of prey consumed by both sexes. Females consumed four categories of prey, while males consumed six categories; Acari and Isoptera were the only orders not shared by males and females. The percentage of diet similarity between sexes was $66.7 \%$ according to the Jaccard index, and 93.74 for QR. On the other hand, there was no association between the morphometric measurements and the number of items found per stomach (SVL: $\mathrm{R}^{2}=0.03861, p=0.3933$; HW: $\mathrm{R}^{2}=0.00308, p=0.81112$ ). Our results suggest that $E$. pearse $i$ is an actively foraging species, with some preference for small invertebrates, mainly ants; these findings are consistent with recent studies about the species that, similarly to our findings, concluded this is a specialist species towards the consumption of ants (Blanco-Torres et al. 2015). However, we believe the trophic range of $E$. pearsei may be wider, as items of some orders found in stomach contents of several individuals had not been pre-

Table 1. Composition of preys present in the diet of Elachistocleis pearsei $(\mathrm{n}=21)$ in a lentic ecosystem in the department of Sucre. $\mathrm{N}^{\circ}$ items $=$ number of eaten items; $\%=$ percentage of prey; $\mathrm{ni}=$ number of stomachs containing any category of prey; IIA \% = index of dietary importance.

\begin{tabular}{lcccc}
\hline Prey & $\mathrm{N}^{\circ}$ Items & $\%$ & $\mathrm{ni}$ & $\mathrm{IIA} \%$ \\
\hline $\begin{array}{l}\text { Hymenoptera } \\
\text { (Formicidae) }\end{array}$ & 280 & 95.56 & 20 & 91.01 \\
$\begin{array}{l}\text { Coleoptera } \\
\text { (Scarabaeidae) }\end{array}$ & 3 & 1.02 & 3 & 0.150 \\
Orthoptera & 2 & 0.69 & 2 & 0.065 \\
Diptera & 3 & 1.02 & 3 & 0.150 \\
Acari & 3 & 1.02 & 2 & 0.101 \\
Isoptera & 2 & 0.69 & 1 & 0.036 \\
Total & 293 & & 21 & \\
\hline
\end{tabular}

Table 2. Frequency of males and females of Elachistocleis pearsei in three time intervals during their activity period (value of Chi-squared test).

\begin{tabular}{ccc}
\hline Time interval & Males & Females \\
\hline 19:00-20:00 & 8 & 7 \\
20:01-21:00 & 2 & 5 \\
21:01-22:00 & 2 & 0 \\
$\left(\mathrm{X}^{2}=3.3524, \mathrm{df}=2, p=0.18709\right)$ & \\
\hline
\end{tabular}


viously reported, such as Diptera, Coleoptera (Subfamily Aphodiinae) and Orthoptera, although their indexes of dietary importance were not very high: IIA $=0.150 \%$, $0.150 \%$ and $0.065 \%$, respectively (Table 1 ). Studies on the diet of another species of the family Microhylidae have shown similar results to ours (Van Sluys et al. 2006; López et al. 2007); it is common to find ants as the most representative group in the diet of these frogs. The temporal similarity of the trophic niche between males and females could explain the similar composition of their diet because all the individuals actively forage for prey at the same time during the night, when all of them have the same probability of eating the same groups of arthropods.

Finally, it was evidenced that the non-invasive method applied is effective and decreases the impact on the population to a minimum, allowing the analysis of larger sample sizes; also, this study improves our knowledge about the natural history of the species in the lowlands of the Colombian Caribbean.

ACKNOWLEDGEMENTS. The authors thank Dr. Alcides Sampedro and two anonymous reviewers for helpful comments on the manuscript, and to the Universidad de Sucre for granting permission to carry out our work in the campus Puerta Roja; the Laboratory management center allowed us to use equipment and laboratory spaces.

\section{LITERATURE CITED}

Acosta-Galvis, A. R. 2012. Anfibios de los enclaves secos del área de influencia de los Montes de María y la ciénaga de La Caimanera en el Departamento de Sucre. Revista Biota Colombiana, 13, 211 231.

Aguilera, M. 2005. La economía del departamento de Sucre: Ganadería y sector público. Documentos de trabajo sobre economía regional 69. Bogotá, Banco de la República, 129 pp.
Blanco-Torres, A. 2009. Repartición de microhábitat y recursos tróficos entre especies de Bufonidae y Leuperidae (Anfibia: Anura) en áreas con bosque seco tropical de la región Caribe, Colombia. Tesis presentada para optar el título de Maestría en Biología. Bogotá, Universidad Nacional de Colombia, Facultad de Ciencias, Departamento de Biología.

Blanco-Torres, A., Duré, M. \& Bonilla, M. A. 2015. Observaciones sobre la dieta de Elachistocleis pearsei y Elachistocleis panamensis en dos áreas intervenidas de tierras bajas del norte de Colombia. Revista Mexicana de Biodiversidad, 86, 538-540.

IAvH -Instituto de Investigación de Recursos Biológicos Alexander von Humboldt. 2014. El Bosque Seco Tropical en Colombia. Bogotá, D.C., Colombia.

López, J. A., Ghirardi, R., Scarabotti, P. \& Medrano, M. 2007. Feeding ecology of Elachistocleis bicolor in a riparian locality of the middle Paraná River. The Herpetological Journal, 17, 48-53.

Miles, L. A., Newton, C., DeFries, R. S., Ravilious, C., May, I., Blyth, S., Kapos, V. \& Gordon, J. E. 2006. A global overview of the conservation status of tropical dry forests. Journal of Biogeography, 33, 491- 505.

Muñoz-Guerrero, J., Serrano, H. \& Ramírez, P. M. 2007. Uso de microhabitat, dieta y tiempo de actividad en cuatro especies simpátricas de ranas Hylidas neotropicales (Anura: Hylidae). Caldasia, 29, 413-425.

Odum, E. 1984. Ecología. Nueva Editorial Interamericana, S. A. de C. V., México, D. F.

Sampedro, M. A., Angulo, V. Y., Arrieta, D. F. \& Atencia, D. D. 2011. Alimentación de Bufo marinus (Linnaeus, 1758) (Bufonidae: Anura), en el Departamento de Sucre, Colombia. Caldasia, 33, 495-505.

Solé, M., Beckmann, O., Pelz, B., Kwet, A. \& Engels, W. 2005. Stomach-flushing for diet analysis in anurans: an improved protocol evaluated in a case study in Araucaria forests, southern Brazil. Studies on Neotropical Fauna and Environment, 40, 23-28.

Toft, C. A. 1985. Resource partitioning in Amphibians and Reptiles. Copeia 1985, 1-21.

Van Sluys, M., Schittini, G., Marra, R., Azevedo, A., Vicente, J. J. \& Vrci-bradic, D. 2006. Body size, diet and endoparasites of the microhylid frog Chiasmocleis capixaba in an Atlantic Forest area of Southern Bahiastate, Brazil. Brazilian Journal of Biology, $66,167-173$. 